\title{
LABVIEW ALAPÚ MOZGÁS TERVEZÉSE ÉS NYOMON KÖVETÉSE IPARI ROBOT MANIPULÁTOR SZÁMÁRA (KUKA KR5 ARC): TERVEZÉS, MODELLEZÉS ÉS ROBOT VEZÉRLŐEGYSÉG SZIMULÁCIÓJA
}

\section{LABVIEW MOTION PLANNING AND TRACKING OF AN INDUSTRIAL ROBOTIC MANIPULATOR (KUKA KR5 ARC): DESIGN, MODELLING AND SIMULATING THE ROBOT'S CONTROLLER UNIT}

\author{
Nwachukwu C. Obinna ${ }^{1}$, Timotei Istvan Erdei ${ }^{2}$, Zsolt Molnar $^{3}$, Peter Szemes ${ }^{4}$, Geza Husi ${ }^{5}$ \\ ${ }^{1-5}$ Department of Electrical Engineering and Mechatronics, Faculty of Engineering, \\ University of Debrecen, address: Otemeto utca 2-4, 4028, Debrecen, Hungary \\ Inwachukwucobinna@gmail.com, '2timoteierdei@gmail.com, ${ }^{3}$ zsolt.molnar94@gmail.com, \\ 4szemespeter@eng.unideb.hu, ${ }^{5}$ husigeza@eng.unideb.hu
}

\begin{abstract}
Robots are susceptible to malfunctions. A class of these malfunctions, known as singularities, occur due to the mathematical nature of the robot's control law. This paper proposes a means of measuring the robot's response in configuration, and operational space. In order to invite more research on tackling the issue of singularity, we have developed a simulator in the labVIEW environment. The simulator is able to plot configuration and operational space responses on a $2 \mathrm{D}$ graph, allowing the user to easily observe how the robot responds when given a certain command. The user is able to cite singularities, by simply pointing out specific abnormalities on the response graph.
\end{abstract}

Keywords: singularity, manipulator, labVIEW, simulator, KUKA, controller, measurement, response

\section{Összefoglalás}

Az általánosan alkalmazott robotok hajlamosak meghibásodásra. A hibák jelentős része a szinguralitásra vezethető vissza, ami eredeztethető a robot vezérlőjének matematikai sajátosságából. A tanulmány méréseinek alapjául a robot konfigurációja és annak munkatere szolgált. Annak érdekében, hogy más kutatók is vizsgálatokat tudjanak kezdeményezni a szinguralitás témájában, egy saját labVIEW alapú szimulációs környezet került kidolgozásra. A szimulátor képes $2 \mathrm{D}$ grafikonon ábrázolni egy adott konfiguráció és annak munkaterületén való müködését, segítve ezzel a felhasználót hogy tanulmányozható legyen a viselkedése a kiadott parancs függvényében. Ezzel a módszerrel képes szinguralitást modellezni és kimutathatóak specifikus rendellenességekre a grafikon alapján..

Kulcsszavak: szimguralitás, manipulátor, labVIEW, szimulátor, KUKA, vezérlö, mérés, válaszidö

\section{Introduction}

This paper highlights several parts of the department's ongoing research on industrial manipulator singularities. Due to the closed source nature of the KUKA KR5 arc situated within the department's robotic laboratory, we developed a sustainable research strategy. A sustainable research strategy must be cost effective, flexible, and extensible. Developing a simulator in the 
labVIEW environment is a significant part of this strategy. The end goal of the simulator development project, is a simulator that almost exactly mimics the robot's real-time motion, allows modifications to be made easily, and has a relatively simple graphical user interface (GUI). At the time of writing this paper, we had successfully built a functional simulator. The simulator is based upon a basic model of the KR5's controller unit.

\section{The Robot's Dynamics}

\subsection{Deriving the equations of motion in configuration space}

Synchronous servo motors are responsible for the motion of the robot's joints. The motors' stator and rotor windings are resistive in nature. It is also important to note that friction exists between the relative motion of the stator and rotor elements. The total mechanical dissipative forces, $\mathfrak{R} \mathrm{em}$, acting at each joint may be derived as the following,

$$
\left(\frac{d \Re_{e m}}{d q}\right)_{i}=r\left(\dot{q}_{l}\right)=B_{i} \dot{q}_{l}
$$

where, $B_{i}$ is coefficient of friction between the $\mathrm{i}^{\text {th }}$ motor's stators and rotors.

The extended Euler-Lagrange equation may be written as,

$$
\boldsymbol{A}(\boldsymbol{q}) \ddot{\boldsymbol{q}}+\boldsymbol{b}(\boldsymbol{q}, \dot{\boldsymbol{q}})+\boldsymbol{g}(\boldsymbol{q})+\boldsymbol{r}=\boldsymbol{\tau}
$$

where, $\mathbf{q}$ is the joint displacements and $\mathbf{A}(q)$ is the robot's kinetic energy matrix, it incorporates the robot's mass properties, and is obtained as follows.

\subsection{Deriving the equations of motion in operational space}

One might ask the question. What is operational space? Operational space coordinates may represent any set of coordinates defining kinematic mapping between configuration space and operational space. Pay attention to the fact that the model derived in the previous section, does not capture constraint forces acting on the system. Equations derived from modeling in operational space, in combination with those derived previously in configuration space, will produce a concise system of equations that take into account the effect of the constraint forces. The operational space configuration vector, $\mathrm{x}$, describing the position and orientation of an arbitrary point on the system, may be derived from the system's kinematics. The system's kinematics equates the operational space configuration vector, as a function of the generalized configuration space coordinates.

$$
\boldsymbol{x}=\boldsymbol{\xi}_{E}=\boldsymbol{f}(\boldsymbol{q}) \in \mathfrak{R}^{1 \times m}
$$

The operational space velocities are the time derivatives of $\mathbf{x}$.

$$
\dot{\boldsymbol{x}}=\frac{\partial \boldsymbol{f}(\boldsymbol{q})}{\partial \boldsymbol{q}} \dot{\boldsymbol{q}}, \boldsymbol{J}=\frac{\partial \boldsymbol{f}(\boldsymbol{q})}{\partial \boldsymbol{q}} \in \mathfrak{R}^{m \times n}
$$

where $\mathrm{J}(\mathrm{q})$ is the kinematic Jacobian.

The kinetic energy in operational space is expressed as

$$
T=\frac{1}{2} \dot{\boldsymbol{x}}^{T} \boldsymbol{\Lambda}(\boldsymbol{x}) \dot{\boldsymbol{x}}, \quad \boldsymbol{\Lambda}(\boldsymbol{x}) \in \Re^{m \times m}
$$

where $\boldsymbol{\Lambda}(\mathbf{x})$ is the operational space kinetic energy matrix.

\section{Version 1.0 of the Simulator}

We chose to divide the controller unit into three parts; trajectory planner, PID controller, and servo drive. Although the controller unit is made up of only three parts, the simulator is made up of a total of four parts. This additional part is the plant model of the KR5. The simulator was built and tested on a Lenovo IdeaPad Y700, with 16 gigabytes RAM and a 2.6 gigahertz Intel Corei7 CPU. LabVIEW's Control Design and Simulation Module was an integral part of developing the simulator.

The simulator package consists of several labVIEW virtual instrument (.vi) files; a main .vi file, and a set of simulation sub- 

számára (KUKA KR5 arc): tervezés, modellezés és robot vezérlőegység szimulációja

system files. A simple GUI is located in the front panel of the main .vi file. The GUI allows the user to tune the PID controllers, plan trajectories in the world coordinate frame, and observe the robot's response to the trajectories previously mentioned.

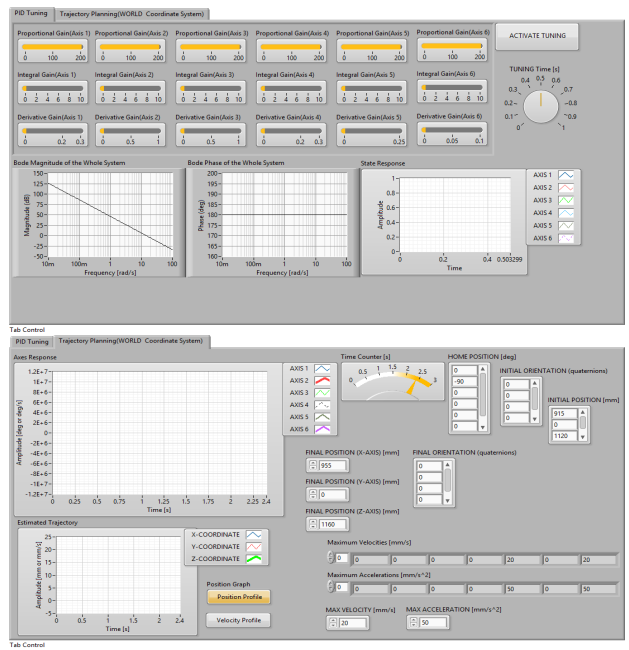

Fig. 1..Simulator's Graphical User Interface (GUI)

\section{Plant Model}

The model was constructed within the framework of the computed torque control law. The plant model is a six jointed kinematic structure, where each joint is a revolute type joint. Actuation of each joint is achieved by torque generated from a servo motor's shaft. The shaft's torque is controlled by altering the servo motor's electrical current supply. This change in electrical current generates enough electromotive force (emf) to drive the motor. Torque is analogous to the emf.

\section{Servo Drive Model}

A servo drive may be used due to the fact that the robot's actuators are servo motors (servo mechanisms). The servo drive is a special class of an amplifier circuit. The command signal of the drive represents a desired torque, velocity, or position, and its output is the required electromotive force for driving the motor's shaft. The servo drive may be modeled in the following manner,

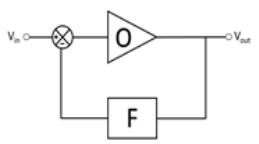

Fig. 2. Simplified Circuitry of the Servo Drive $O=$ open loop gain, $F=$ feedback loop gain.

$$
\frac{V_{\text {out }}}{V_{\text {in }}}=G=\frac{O}{1+(\boldsymbol{O} * F)}
$$

where, $\mathbf{G}$ is the closed loop gain and may be regarded as the transfer function of the servo drive.

Having $\ddot{\mathbf{q}}$ as $\mathbf{V}_{\text {in }}, \mathbf{O}$ is then equal to $\mathbf{A}(\mathbf{q})$, while $\mathbf{F}$ may be tuned online. The servo drive features two sets of input $\mathbf{V}_{\text {in }}$, as well as the feedback signal (velocity signal from encoder).

\section{PID Controller Model}

The PID controller ensures smooth response to a desired set point. This set point may be a position, or velocity command, depending on what you wish to control. If one wishes to control velocity (which is the case for our simulator), then the PID controller's output is acceleration. However, if one wishes to control position, then the PID controller's output is velocity. Within the labVIEW environment, the PID controller model is developed as a simulation subsystem and controls all six joints of the KR5.

\section{Trajectory Planner Model}

A trajectory planner as its name suggests, allows the individual to plan trajectories for a robot. What does this mean? In the previous section, we mentioned the velocity of each joint is controllable. In fact, all that we do have control over are the joint velocities. Kinematic mapping enables one to command the robot's motion in operational space, by generating the necessary 
joint velocities. The Jacobian matrix is a kinematic mapping tool. Within the labVIEW environment, the trajectory planner model is developed as a simulation subsystem. Although the trajectory planner may be found in a subsystem, the calculation of the Jacobian is found in a MATLAB Script Node. In practice the Jacobian is usually calculated numerically, but within our simulator it is not. The complexity of calculating the Jacobian requires enough software and hardware computing power. The MATLAB Script Node launches a MATLAB server,

\section{Conclusion}

The first functional version of the simulator is currently available online for further development, and educational purposes. We have carried out several basic tests in order to evaluate the performance of the simulator. The criteria of these tests include; error of the simulator from expected values, observability of singularity points. These tests showed us that the simulator operates with a maximum and minimum error of $\pm 2 \mathrm{~mm}$ from the expected trajectory, and singularity points are observable.

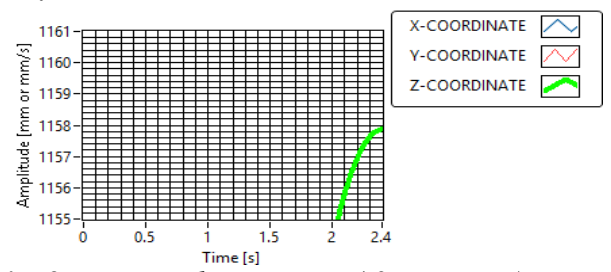

Fig. 2. Estimated Trajectory (-2 mm error)
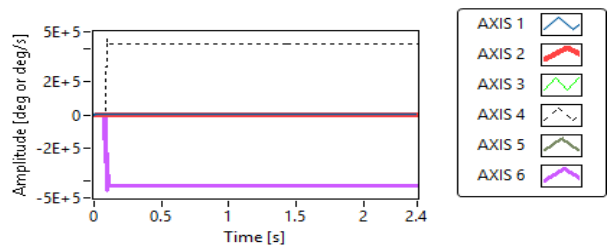

Fig. 3. Singularity Point (joint velocities tending to infinity)

\section{Acknowledgement}

The research work presented in this paper is inspired by the works of Dr. Péter Szemes in the field of control systems, and that of Dr. Géza Husi in the field of robot singularities. These two esteemed individuals provided us with all the support we needed while developing the simulator. A big thank you also goes out to MATLAB, labVIEW, KUKA, and Google for providing the world with cutting edge systems

\section{References}

[1] G. Liu, Y. Lou, Z. Li, Singularities of Parallel Manipulators: A Geometric Treatment, IEEE Transactions on Robotics and Automation, vol. 19, no. 4, August 2003.

[2] S. Chiaverini, Singularity-Robust TaskPriority Redudancy Resolution for Real-Time Kinematic Control of Robot Manipulators, IEEE Transactions on Robotics and Automation, vol. 13, no. 3, June 1997.

[3] K.A. Das et al.: A Vision-Based Formation Control Framework, IEEE Transactions on Robotics and Automation, vol. 18, no. 5, October 2002.

[4] G. Husi: Position Singularities and Ambiguities of the KUKA KR5 Robot, International Journal of Engineering Technologies, vol.1, no.1, 2015.

[5] A.D. Udai et al.: Dynamic Simulation of a KUKA KR5 Industrial Robot using MATLAB SimMechanics, 15th National Conference on Machines and Mechanisms.

[6] G. Husi, et al.: Building Mechatronics Research Centre as energy aware Intelligent Space, Industrial Electronics Society, 39th Annual Conference of the IEEE, January 2013.

[7] G. Husi, P. T. Szemes, E. Dávid, T. I. Erdei, G. Petö: Reconfigurable Simulation and Research Toolset for Building Mechatronics, Workshop on Cognitive and Eto-Robotics in iSpace, July 2013.

[9] A. Sabanovic, K. Ohnishi, Motion Control Systems, IEEE Press.

[10] F. L. Lewis, D. M. Dawson, Robot Manipulator Control Theory and Practice, Marcel Dekker Inc.

[11] P. Corke, Robotics Vision and Control, Springer. 